\title{
First Report of Powdery Mildew Caused by Podosphaera fusca on Trichosanthes kirilowii var. japonica in Korea
}

\author{
Jin-Hyeuk Kwon ${ }^{1}$, Okhee Choi ${ }^{2}$, Hyeon-Dong Shin $^{3}$ and Jinwoo Kim ${ }^{2 *}$ \\ ${ }^{1}$ Gyeongsangnam-do Agricultural Research and Extension Services, Jinju 660-360, Korea \\ ${ }^{2}$ Institute of Agriculture and Life Science, Gyeongsang National University, Jinju 660-701, Korea \\ ${ }^{3}$ Division of Environmental Science and Ecological Engineering, Korea University, Seoul 136-701, Korea \\ (Received on January 11, 2011; Accepted on April 17, 2011)
}

Trichosanthes kirilowii var. japonica Kitam., the Japanese snake gourd, is a herbaceous perennial twining vine in the Cucurbitaceae. The plant has long been considered a medicinal herb and is a source of trichosanthin, a compound with anti-HIV activity. Powdery mildew on T. kirilowii var. japonica is usually first noticed in late spring and early autumn but often be observed throughout the whole growing season. Severe infection with powdery mildew of wild T. kirilowii var. japonica has been observed at several localities in southern Korea, including Seoguipo, Busan, Wando, and Sacheon. The leaves become covered with dense white mycelial mats that produce abundant conidia (Fig. 1A, B). Voucher specimens are deposited at KoreaUniversity, Seoul, Korea(KUS-F22457, 25391,25634,25658).

To identify the powdery mildew fungus, fresh material including anamorphs and teleomorphs of the causal fungus was examined using standard light microscopy (Carl Zeiss, Göttingen, Germany). Hyphal appressoria were nipple-shaped or nearly absent. Conidiophores were 100-250 $\times 10-15 \mu \mathrm{m}$, slightly swollen at the base of foot cells, arising from the upper part of hyphae, and producing conidia in chains with sinuate edges (Fig. 1C). Conidia were oval to ellipsoidal with distinct fibrosin bodies, and measured 24-35×14$20 \mu \mathrm{m}$ (Fig. 1D). Chasmothecia were $80-120 \mu \mathrm{m}$ in diameter and blackish-brown (Fig. 1E-G). Appendages were brown at the base and paler towards the top, simple but irregularly branched in the upper portion, septate, hypha-like, and interwoven with the hyphae of the surrounding mildew colony (Fig. 1F). A single, thick-walled ascus was contained in a chasmothecium (Fig. 1G). There were eight ascospores in an ascus, which were ellipsoidal to oval, and 20 $30 \times 14-20 \mu \mathrm{m}$. The observations and measurements agree fully

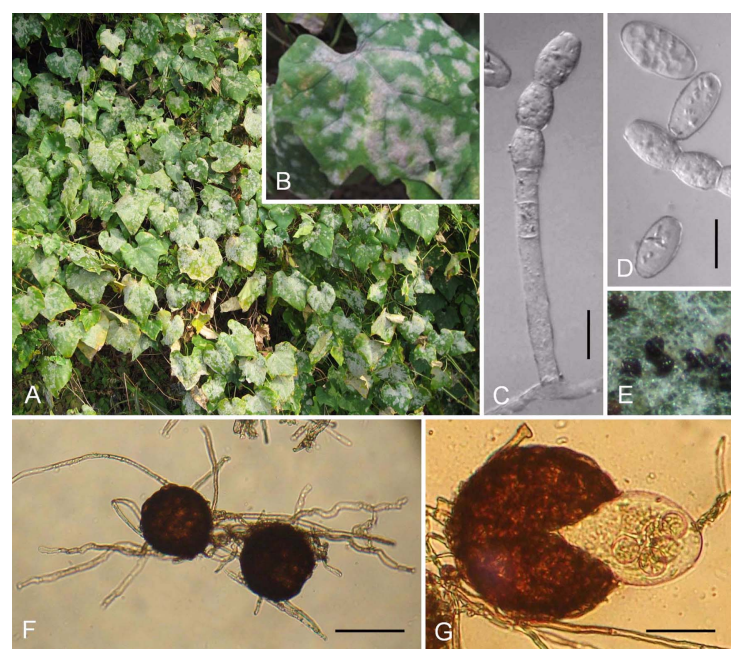

Fig. 1. Powdery mildew infections of Trichosanthes kirilowii var. japonica caused by Podosphaera fusca. A: Heavy infections of powdery mildew in natural habitat. B: A close-up view of leaf infection. C: Conidiophore (bar $=20 \mu \mathrm{m})$. D: Conidia $($ bar $=20 \mu \mathrm{m})$. E: Colonies of powdery mildew with chasmothecia. F: Chasmothecia with appendages $($ bar $=100 \mu \mathrm{m})$. G: Chasmothecium with ascus (bar $=50 \mu \mathrm{m})$. with previous records of Podosphaera fusca (syn. Sphaerotheca fusca) (Braun, 1987; Shin, 2000).

To confirm the identity of the causal fungus, amplification and sequencing of the complete ITS rDNA of the representative isolate (KUS-F25658) was carried out using primers ITS1 and ITS4, as described by White et al. (1990). The resulting 563-bp sequence has been deposited in GenBank (Accession No. HQ683746). Phylogenetic analysis was performed with MEGA4 software using the neighbor-joining method and the Tajima-Nei distance model. The isolate showed only two base substitutions with the sequence (AF011319) from P. fusca infecting Cucurbita pepo (Fig. 2). Therefore the sequence analysis verified the pathogen as $P$. fusca.

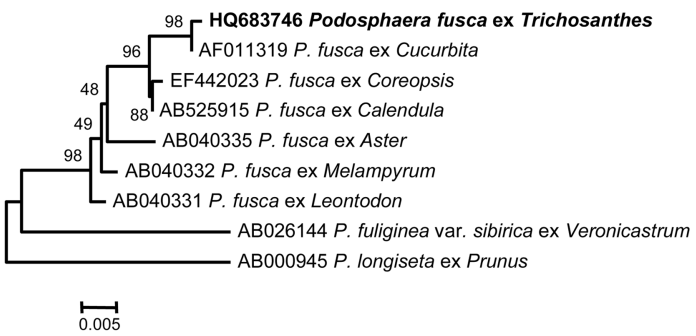

Fig. 2. Phylogenetic relationships among Podosphaera fusca isolates, including a powdery mildew fungus infecting Trichosanthes kirilowii var. japonica (bold), based on a similarity analysis of rDNA ITS sequences. The numbers above the branches indicate bootstrap values. Bars indicate the number of nucleotide substitutions per site.

In Korea, several cucurbitaceous hosts, e.g., Citrullus, Cucumis, Cucurbita, Lagenaria, Melothria and Thladiantha, are infected with P. fusca (Shin, 2000; The Korean Society of Plant Pathology, 2009). However, there is no previous record of $P$. fusca on Trichosanthes in Korea. This is the first record of powdery mildew of T. kirilowii var.japonica caused by P. fusca in Korea.

\section{Acknowledgment}

This work was carried out with the support of "Cooperative Research Program for Agriculture Science \& Technology Development (PJ007345)" Rural Development Administration, Korea.

\section{References}

Braun, U. 1987. A Monograph of the Erysiphales (Powdery Mildews). Beihefte zur Nova Hedwigia 89:1-700.

Shin, H. D. 2000. Erysiphaceae of Korea. National Institute of Agricultural Science and Technology. Suwon, Korea.

The Korean Society of Plant Pathology. 2009. List of Plant Diseases in Korea. 5 th ed. (in Korean)

White, T. J., Bruns, T., Lee, S. and Taylor, J. W. 1990. Amplification and direct sequencing of fungal ribosomal RNA genes for phylogenetics. In: PCR Protocols: A Guide to Methods and Applications, ed. by M. A. Innis, D. H. Gelfand, J. J. Sninsky, and T. J. White. pp. 315-322. Academic Press, New York.

*Corresponding author (jinwoo@gnu.ac.kr) 